\title{
The Effect of Dividend Policy on Share Price: An Evaluative Study
}

\author{
Md. Abdullah Al- Hasan ${ }^{1,}$ Md. Asaduzzaman ${ }^{2,}$ Rashed al Karim ${ }^{3}$ \\ (Lecturer, Department of Finance and Banking, University of Chittagong) \\ (Lecturer, Business Administration, East Delta University, Bangladesh) \\ (Assistant Professor, Business Administration, East Delta University, Bangladesh)
}

\begin{abstract}
The most debated issue in the field of finance is over the effect of dividend policy on market price per share. There are huge literatures for and against this wisdom. The current study has been undertaken aiming at evaluating the effect of dividend policy on market price of share in the context of Bangladesh. The study has covered secondary data and analyzed the data by employing descriptive statistics, correlation and multiple regression models. It has tested hypothesis by using $F$ test. The study has found that the effect of dividend payout is more on market price than retention. This dependency is significant at $1 \%$. Finally, the paper concludes that the findings over the effect of dividend policy on market price supports the relevant theory of dividend policy i.e. Walter's model and Gordon's model.
\end{abstract}

Key words: Dividend policy, Market price per share, Earning per share

\section{Introduction:}

Dividend decision being one of the important financial decisions of a corporate firm has been still a most debated issue across the world. There are extensive literatures, theories, and models for facilitating dividend decisions. The finance world is receiving new literatures/ models every year from the researchers/academicians either in the new form or expansion of existing models. After the Modigliani-Miller (1961) paradigms on firms' dividend policy and their market values, there have been considerable debates, both in theoretical and empirical researches on the nature of relationship that exists between a firm's choice of dividend policy and its market value. Debates have centered on whether $100 \%$ dividend payout ratio or $100 \%$ retention ratio or the mix of dividend payout and retention is optimal dividend decision that affect the value of the firm and shareholder's return. Although, there have been substantial research efforts devoted by different scholars in determining what seems to be an optimal dividend policy for firms, yet there is no universally accepted theory throughout the literature explaining the dividend payout and retention choice of firms. But in the last decades, several theories have emerged explaining firms' dividend policy and the resultant effects on their market values. These theories include the dividend irrelevance theory which asserts dividends do not really matter because they do not affect the firm value (Modigliani-Miller 1961); the dividend relevance theory which asserts dividend policy affect the value of a firm. The choice of dividend policies almost always affects the value of the firm (Walter, 1963). The dividend policy does affect the value of a share even when rate of return equal to cost of capital (Gordon, 1962).

The financial market in Bangladesh is liberalized. The economy of Bangladesh is characterized by different kinds of firms. So firms differ on sizes, registered or unregistered, ownership structure, listed or unlisted etc. So, dividend decision thereto differs from firm to firm. An optimal dividend decision is taken on some important criteria- shareholders' return, growth of a firm and the value of a firm. Besides, there are some important factors that influence the dividend decision of a corporate firm. The factors are related to firm's investment opportunities and financial needs, shareholders' expectations, constraints on paying dividends, legal restrictions, liquidity, financial condition and borrowing capacity, access to the capital market, restrictions in loan agreements, inflation, control, (Weston \& Brigham, 1972; Brandt, 1972; Van Horne, 1976). The dividend decision involves an analysis of dividend payout and retention, and the relevant factors that influence the proportion of dividend to EPS and retained earnings to EPS (Ali \& Recep, 2012). The dividend decision of a company suggests a change in dividend payout ratio and retention ration. The dividend policy has implications for the shareholder's earnings and growth of a firm (Adelegan, 2008). The firm always expects an optimal dividend policy that strikes between shareholders' return and growth of a firm so as to maximize the price of the stock in the stock market.

\section{Literature Review:}

Several studies have been conducted on Dividend Policy by different scholars in different period of time. The correlation of price volatility and dividend yield is quite significant as compare to other variables (Asghar, Shah, Hamid \& Suleman, 2011). Dividend policy has positive influence on stock prices (Murhadi, 
2008). dividend-paying firms have a more liquid market for their stock and measures of a stock's liquidity is positively linked to its probability of being a dividend payer (Igan, Paula \&Pinheiro, 2010). The cumulative excess returns (CERs) for dividend paying firms are positive and significant for 30 days from the day of the announcement, while the CERs for dividend omitting firms for the same period are significant and negative (Adelegan, 2009). Larger firms, those with higher profitability, and firms with low growth opportunities have a greater propensity to pay dividends. There has been a significant decline in the average dividend payout ratios over the years (Fatemi \& Bildik, 2012). Stock market evidence shows that momentum profits are lower among dividend-paying firms than their non-paying counterparts due to differences in losers' returns (Asem \& Ebenezer, 2009). When the corporate financial policy implies now some default risk, we show that the value of the firm is a piecewise decreasing functions of the dividend policy for any leverage policy, so that dividend policy affects the value of the firm (Braouezec \& Lehalle 2010). There is a significant positive association between the performance of firms and the dividend payout of the sampled firms in Nigeria (Uwuigbe ,Jafaru \& Ajayi, 2012). Dividends are not a value-relevant in the presence of earnings in the valuation model (Al-Hares, AbuGhazaleh \& Haddad, 2012). The performance generally improves with an increasing dividend yield (Henne, Ostrowski \& Reichling 2007). Dividend increase announcements are greeted positively by investors, while there are some evidences suggesting investors react negatively prior to dividend decrease announcements (Jais, Karim, Funaoka, \& Abidin, 2009). The bird- in- hand theory received the highest support ( Naser, Nuseibeh \& Rashed,2013). There was a tendency in America where a decline in the share price reaction to announcement of dividend payments since mid-1978 (Ammihud and Li 2002). The empirical results of this study showed significant negative relationship between share price volatility with two main measurements of dividend policy which are dividend yield and dividend payout (Hashemijoo, Ardekani, \& Younesi, 2012). The results of this study show a positive and significant relationship between cash dividends, retained earnings, earnings per share, and stock price while stock price is positively (Asem \& Tian, 2010).

\section{Objectives of the study:}

The principal objective of the study is to evaluate the effect of dividend policy on share price of some selected listed companies in Bangladesh. To accomplish this objective following specific objectives have covered:

- To highlight the dividend policy of each industry

- To examine the relationship between dividend per share and share Price

- To assess the relationship between retained earnings and share Price

- To evaluate the dependency of dividend per share and retained earnings on share price

- To draw inferences on the basis of analysis

\section{Hypotheses of the Study:}

Hypothesis is the statement that shows the inferred relationship among different variables. The conjectured relationships between the variables are established on the basis of available literature. These relationships can be verified using certain statistical tests or techniques. These hypotheses may be substantiated or not, depending upon the results derived from statistical analysis. As per the objectives of the study, the following hypothesis was developed for testing:

$\mathbf{H}_{1}$ : Dividend policy has significant effect on share price

So the hypothesis is-

Ho: There is no significant effect of dividend policy on share price

$\mathbf{H}_{\mathbf{A}}$ : There is a significant effect of dividend policy on share price

\section{Data Collection Technique:}

\section{Methodology of the Study:}

This study is based on the secondary data. This study covers four industries -Automobile, Cement, Textile and Pharmacy. Total 28 companies have selected 7 companies from each industry for the period of 2005 to 2009. The study based on secondary data and annual report of each company collected as a source of secondary data.

\section{Data Processing and Analyzing Technique:}

SPSS 17.0 and Excel have been used to process and analyze the data. Dependent and independent variables are analyzed by using correlation and linear regression. Statistical tools like Regression analysis, F-test have been used to assess and interpret data. Regression analyses have been used to analyze the relationship of dividend policy with share price of companies. F-tests have been performed to test the statistical significance of the parameters at $1 \%$ level of significance. 


\section{Specification of the Models:}

The sample of the study is trimmed applying a methodology to test the effect of dividend policy on share price by multiple regression analysis using least square estimation method. Assumption on which least square estimation method is based include a) relationship between dependent and independent variables is linear, b) residual term to be normally distributed with zero expectation, not correlated with independent variables and have constant variance. According to these empirical models, shareholders returns are affected by the variables shown in these following equations:

$\mathrm{MPPS}=\alpha+\beta_{1} D P S+\beta_{2} R E P S+\varepsilon$

Where,

MPPS $=$ Market price per share

DPs=Dividend per share

REPS $=$ Retained earnings per share

$\alpha=$ Constant term of the model

$\beta=$ Coefficients of the model

$\varepsilon=$ Error term

Dependent variables: Market price per share (MPPS)

Independent variables:

a) Dividend per share

b) Retained earnings per share

* Table-1: Descriptive Information of Variables Descriptive Statistics

\begin{tabular}{|l|r|r|r|r|r|}
\hline & \multicolumn{1}{|c|}{ N } & \multicolumn{1}{c|}{ Minimum } & Maximum & \multicolumn{1}{c|}{ Mean } & \multicolumn{1}{c|}{ Std. Deviation } \\
\hline DPS & 140 & .00 & 75.00 & 8.7017 & 14.16760 \\
REPS & 140 & -159.54 & 202.02 & 12.6375 & 38.24242 \\
MPPS & 140 & 2.88 & 3365.00 & 402.2445 & 620.51918 \\
Valid N (list wise) & 140 & & & & \\
\hline
\end{tabular}

Source: Data are gathered from the annual report of concerned companies, BD stock price and result of statistical calculation.

In addition to these two regression analyses, the coefficient of determination $\left(\mathrm{R}^{2}\right)$ also used to analysis the variance and to justify the accuracy of the models developed in this study. The study has also used adjusted coefficient of determination $\left(\mathrm{AR}^{2}\right)$ to justify whether the value of $\mathrm{R}^{2}$ is increased for using the two independent variables. The study has tested individual coefficient by using t-test at the $5 \%$ level of significance. The way the alternate hypothesis is stated indicates that the test is two tailed.

Even though, the least square method has the ability to draw the inferences about the relationship for an entire population, the study have tested the ability of the independent variables to explain the behavior of the dependent variable by using a global test that is called F-test.

Averages, standard deviation, correlation, beta regression analysis, coefficient of determination, F-test and t-test have been calculated by using SPSS 17.0 for windows.

Dividend Payout Policy:

\section{Findings and Analysis:}

The dividend payout policy of the some listed companies under different industries in Bangladesh is explained by the table-2.

Table-2: Results Showing the Dividend Payout Ratio
\begin{tabular}{|c|c|r|r|r|}
\hline \multicolumn{1}{|c|}{ Year } & Auto & \multicolumn{1}{c|}{ Cement } & \multicolumn{1}{c|}{ Textile } & \multicolumn{1}{c|}{ Pharmacy } \\
\hline 2005 & 0.334369 & 0.075714 & 0.54 & 0.6 \\
\hline 2006 & 0.342143 & 0.128 & 0.4 & 1 \\
\hline 2007 & 0.134143 & 0.085 & 0.054 & 0.53 \\
\hline 2008 & 0.134286 & 0.201429 & 0.053 & 1 \\
\hline 2009 & 0.103143 & 0.192857 & 0.6 & 0.82 \\
\hline Average & .21 & 0.1366 & 0.3294 & 0.79 \\
\hline $\begin{array}{l}\text { Standard } \\
\text { deviation }\end{array}$ & 0.118146 & 0.058761 & 0.262108 & 0.219545 \\
\hline
\end{tabular}

Source: The data are the summarized financial information of dividend payout ratio. [Note: DPR=DPS/EPS] 
The dividend payout ratio, which is dividend as a percentage of earnings, is an important concept of dividend policy. A company can follow either low payout ratio or high payout ratio. Low payout retains much more than high payout and as a consequence, low payout's earnings, dividends and equity investment are growing at a higher rate than that of high payout. Low payout policy means less current dividends, more retained earnings, higher capital gains and perhaps higher market price per share. A high payout policy means more current dividends and less retained earnings, which may result in slower growth and perhaps lower market price per share.

The average payout ratio is higher for pharmaceuticals industry than other industries and which may consequently result in slower growth and perhaps lower market price per share. The average payout ratio is lower for cement industry than other industries and which may consequently result in higher capital gains and perhaps higher market price per share. The earnings volatility of textile industry is higher than other industries because the standard deviation of DPR of this industry is higher than other industries.

\section{Relationship between Dividend per Share and Share Price:}

The study has identified the magnitude of the relationship between dividend per share and share price. This relationship is shown by correlation coefficient matrix. Table- 3 shows the correlation coefficient matrix

Table-3: Correlations between DPS and MPSP

\begin{tabular}{|ll|r|r|}
\hline & & \multicolumn{1}{|c|}{ DPS } & \multicolumn{1}{c|}{ MPSP } \\
\hline DPS & Pearson Correlation & 1 & $.856(* *)$ \\
& Sig. (2-tailed) & & .000 \\
& $\mathrm{~N}$ & 140 & 140 \\
$\mathrm{SP}$ & Pearson Correlation & $.856(* *)$ & 1 \\
& Sig. (2-tailed) & .000 & \\
& $\mathrm{~N}$ & 140 & 140 \\
\hline \multicolumn{2}{|c|}{} \\
\end{tabular}

Source: The data are compiled by the result of the correlation coefficient between DPS and MPSP

From the analysis of correlation coefficient the study has identified that the relationship between dividend per share and share price is positive because the correlation between DPS and MPPS is .856 and the result is significant at lower than $1 \%$ level of significance. The result of correlation supports the relevance theory of dividend policy that means there is a significant positive relationship between dividend per share and market price per share.

Relationship between Retained Earnings per Share and Share Price: Table-4: Correlations Analysis

\begin{tabular}{|ll|r|r|}
\hline & \multicolumn{1}{|c|}{ REPS } & \multicolumn{1}{c|}{ SP } \\
\hline RE & Pearson Correlation & 1 & $.701\left(^{* *}\right)$ \\
& Sig. (2-tailed) & & .000 \\
& $\mathrm{~N}$ & 140 & 140 \\
$\mathrm{SP}$ & Pearson Correlation & $.701\left(^{* *}\right)$ & 1 \\
& Sig. (2-tailed) & .000 & \\
& $\mathrm{~N}$ & 140 & 140 \\
\hline
\end{tabular}

** Correlation is significant at the 0.01 level (2-tailed).

Source: The data are compiled by the result of the correlation coefficient between REPS and SP

From the analysis of correlation coefficient the study has identified that the relationship between retained earnings and share price is positive because the correlation between REPS and MPPS is .701 and the result is significant at lower than $1 \%$ level of significance. The result of correlation supports the relevance theory of dividend policy that means there is a significant positive relationship between retained earnings and market price per share.

\section{Dependency of Share Price on Dividend Policy:} by table- 5

The results of the regression analysis related to hypothesis drawn on shareholder's return are presented 
Table-5: Regression Analysis [Shareholder's Return (EPS)]

\begin{tabular}{|l|l|l|l|l|l|l|l|}
\hline Variables & $\alpha$ and $\beta$ & $\begin{array}{l}\text { Std. } \\
\text { Error }\end{array}$ & t-stat & Level of sig. & $\begin{array}{l}\mathrm{R}^{2} \\
\left(\text { Adj. } \mathrm{R}^{2}\right)\end{array}$ & $\begin{array}{l}\text { F-stat with } \\
(\text { sig. })\end{array}$ & $\begin{array}{l}\text { VIF } \\
\text { MPPS }\end{array}$ \\
& & 304.54 & & & $\begin{array}{l}.763 \\
(.759)\end{array}$ & $\begin{array}{l}220.043 \\
(.000)\end{array}$ & \\
\hline Constant $(\alpha)$ & 87.409 & 30.366 & 2.88 & .005 & & & \\
\hline DPS $\left(\beta_{1}\right)$ & 30.76 & 2.46 & 12.53 & .000 & & 1.815 \\
\hline RE $\left(\beta_{2}\right)$ & 3.73 & .91 & 4.10 & .000 & & 1.815 \\
\hline
\end{tabular}

Source: The data are compiled by the results of statistical analysis of summarized financial information regarded MPPS, DPS and RE.

From the analysis of the effect of dividend policy on the share price the study has found that when the companies pay the dividend then the MPPS is increased by TK 30.76 because slope $\left(\beta_{1}\right)=30.76$ and when the companies retains the earnings then the MPPS is increased by TK 3.73 because slope $\left(\beta_{2}\right)=3.73$. Both the constant and the coefficients are significant at less than 5\% level of significance.

The model developed for MPPS is strong enough because Coefficient of determination $\left(R^{2}\right)=0.763$. It can be said that the MPPS depends upon the dividend policy by $76.3 \%$ and other variables by $23.7 \%$. The result of the model is not biased by the independent variables because adjusted coefficient of determination $\left(\mathrm{AR}^{2}\right)$ $=0.759$ which is nearer to the value of $\mathrm{R}^{2}$ and less than 1 . The multi-co linearity has been checked. The independent variables are not strongly correlated with each other because the value of variance inflation factor (VIF) is less than the upper limit of 10 .

But it is noteworthy that the sign of beta for the DPS and MPPS, \& beta for REPS and MPPS are positive; meaning that if DPS is increased then the MPPS will be increased at a increasing rate and if REPS is increased then the MPPS will be increased at a decreasing rate. From the F test statistics there is no significant evidence to accept the null hypothesis. So, the study has found that there is a significant effect of dividend policy on Share price and the result supports the relevance theory of dividend policy.

\section{Conclusion:}

This study has investigated the relationship between dividend policy and market price per share. MPPS, DPS and REPS are examined. It is hypothesized that there is a significant effect of dividend policy on the share price. The regression model has shown that there is a positive relationship between the MPPS and DPS, and MPPS and REPS. The result has also indicated that highly payout industries have more MPPS than low payout industries. The study has proved that there is a significance effect of dividend policy on MPPS which supports the relevance theory of the dividend policy.

\section{Limitation of the Study:}

This study focused basically the relationship pattern of MPPS and dividend policy and shows the importance of dividend policy in share price that intern effect the wealth maximization goal of a firm. The study used only two independent variables and data for five years. There are various factors affecting firm's shareholders' return such as financial leverage, tax rate, assets performance, employees' contribution, technical knowhow, probability of bankruptcy and so on. There is a large no. of listed companies under different industries in Bangladesh. This study may therefore lacks in revealing complete forces of variables in MPPS. This study covers few listed companies based on which data; it reveals that dividend policy significantly effects on stock holders return. Above mentioned study does not cover analyze the MPPS on other factors in listed companies which creates an opportunity to deal with through investigation.

\section{References:}

[1]. Amihud, Y. \& Li, K. (2002). The Declining Information Content of Dividend Announcement and the Effect of Institutional Holding. Working Paper, Stern School of Business, New York University.

[2]. Ali, F. \& Recep, B. (2012). Yes, dividends are disappearing: Worldwide evidence. Journal of Banking \& Finance. 36(3), pp. 662667

[3]. Adelegan, O.J. (2008). Can a Regional Approach Accelerate Stock Market Development? Empirical Evidence from Sub-Saharan Africa. IMF Working Paper 08/281, Washington: International Monitory Fund.

[4]. Adelegan, O.J. (2009). Price Reactions to Dividend Announcements on the Nigerian Stock Market. AERC Research Paper 188, African Economic Research Consortium, Nairobi.

[5]. Al-Hares, O., Abu-Ghazaleh, N. \& Haddad, A. (2012). Value relevance of earnings, book value and dividends in an emerging capital market: Kuwait evidence. 23(3), 221-234

[6]. Asem, E. (2009). Dividends and Price Momentum. Journal of Banking \& Finance. 33(3), pp. 486-494.

[7]. Asem, E. \& Tian, G. Y. (2010). Market Dynamics and Momentum Profits. Journal of Financial and Quantitative Analysis, 45(6), $1549-62$.

[8]. Braouezec, Y. \& Lehalle, A. (2010). Corporate Liquidity, Dividend Policy and Default Risk: Optimal Financial Policy and Agency Costs. International Journal of Theoretical and Applied Finance. 13(4), 537-576. 
[9]. Brandit, L.K. (1996). Analysis for Financial Management. Englewood Cliffs N.J.: Prentice Hall

[10]. Gordon, M. J. (1962). The Investment, Financing, and Valuation of the Corporation Homewood. Illinois: Irwin Publishers.

[11]. Henne, A., Ostrowski, S. \& Reichling, P. (2007). Dividend Yield and Stability versus Performance at the German Stock Market Faculty of Economics and Management in its series. $14^{\text {th }}$ Annual Meeting of the German Finance Association, Dresden, Sept. $29^{\text {th }}$.

[12]. Hashemijoo, M., Ardekani, A.M. \& Younesi, N. (2012). The Impact of Dividend Policy on Share Price Volatility in the Malaysian Stock Market. Journal of Business Studies Quarterly, 4(1), pp. 119-129.

[13]. Igan, D., Paula, A. \& Pinheiro, M. (2010). Liquidity and Dividend Policy. MPRA Paper with number 29409, University Library of Munich, Germany.

[14]. Jais, M., Karim, B. A., Funaoka, K. \& Abidin, A. Z. (2009). Dividend Announcements and Stock Market Reaction. University Library of Munich, Germany in its series MPRA Paper with number 19779, Posted 12.

[15]. Miller, M. H., \& Modigliani, F. (1961). Dividend policy, growth, and the valuation of shares. the Journal of Business, 34(4), 411433.

[16]. Murhadi, W.R. (2008). Study on Dividend Policy: Antecedent and Its Impact on Share Price. Journal of Manajemen \& Kewirausahaan, 9(1), 1-29

[17]. Naser, K., Nuseibeh, R. \& Rashed, W. (2013). Managers' perception of dividend policy: Evidence from companies listed on Abu Dhabi Securities Exchange. Issues in Business Management and Economics, 1(1), 01-12

[18]. Suleman, M., Asghar, M., Ali Shah, S., \& Hamid, K. (2011). Impact of Dividend Policy on Stock Price Risk: Empirical Evidence from Equity Market of Pakistan.

[19]. Uwuigbe, U., Jafaru, J. \& Ajayi, A. (2012). Dividend Policy and Firm Performance: A Study of Listed Firms in Nigeria. Journal of Accounting and Management Information Systems.11 (3), 442-454

[20]. Van Horne, J.C. (1979). Optimal Initation of Bankruptcy by Debt Holders, The Journal of Finance, 31(3), pp. 897-910.

[21]. Walter, P. (1970). How to Calculate Savings Possible Through Reduction of Working Capital. Financial Executive, pp.50-58.

[22]. Weston, J.F. \& Brigham, E.F. (1972). Managerial Finance. $4^{\text {th }}$ Edn., NY: Holt, Rinehart \& Winston. 